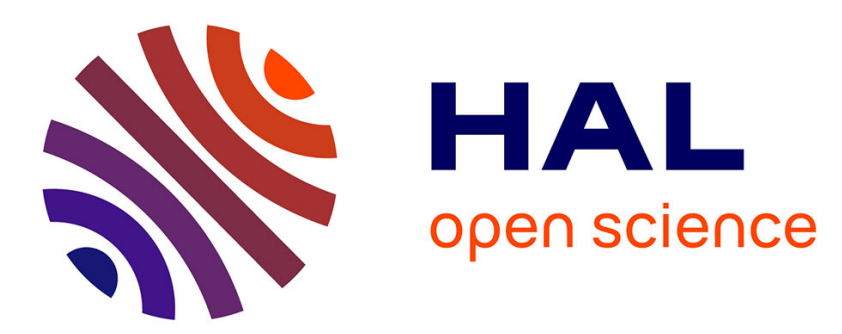

\title{
Analysis of parasite and predator populations observed in pear orchards infested by Psylla pyri (L.) (Hom.: Psyllidae) in France
}

Franck Herard

\section{- To cite this version:}

Franck Herard. Analysis of parasite and predator populations observed in pear orchards infested by Psylla pyri (L.) (Hom.: Psyllidae) in France. Agronomie, 1985, 5 (9), pp.773-778. hal-00884810

\author{
HAL Id: hal-00884810 \\ https://hal.science/hal-00884810
}

Submitted on 1 Jan 1985

HAL is a multi-disciplinary open access archive for the deposit and dissemination of scientific research documents, whether they are published or not. The documents may come from teaching and research institutions in France or abroad, or from public or private research centers.
L'archive ouverte pluridisciplinaire HAL, est destinée au dépôt et à la diffusion de documents scientifiques de niveau recherche, publiés ou non, émanant des établissements d'enseignement et de recherche français ou étrangers, des laboratoires publics ou privés. 


\title{
Analysis of parasite and predator populations observed in pear orchards infested by Psylla pyri (L.) (Hom. : Psyllidae) in France
}

\author{
Franck HERARD (1) \\ European Parasite Laboratory, USDA, ARS, 13-17, rue de la Masse, Béhoust, F 78910 Orgerus
}

\begin{abstract}
Activity periods of the main natural enemies of Psylla pyri (L.), and their succession in pear orchards during the year at Avignon and at Toulouse (France) were determined. Their relative abundance at each sampling date was analyzed using Shannon's formula, which measures the degree of diversity of dominant species. A small number of rather specific beneficial arthropods, Anthocoris nemoralis (F.), Orius spp., Prionomitus mitratus (Dalman) and Trechnites psyllae (Ruschka), was essential to reduce populations of pear psylla notably but not sufficient to control the pest. Their action was enhanced by minor enemies, Orthotylus nassatus (F.). Heterotoma meriopterum (Scopoli), Campyloneura virgula (Herrich-Schaeffer), in June and July.
\end{abstract}

Additional key words : Activity periods, succession of species, dominance diversity index, pear trees.

Mots clés additionnels : Périodes d'activité, succession des espèces, indice de diversité des ennemis dominants de $\mathrm{P}$. pyri, poiriers.

\section{INTRODUCTION}

An inventory of enemies of Psylla pyri (L.), the main pest in pear orchards in France, has been presented in previous paper, (BOUYJOU et al., 1984 ; NGUYEN \& DELVARE, 1984). An annotated list of the entomophagous complex associated with pear psylla is in preparation (HERARD, 1986). Among the 56 beneficial arthropods listed, 16 were fairly abundant. They included 2 parasitoid Encyrtidae, Prionomitus mitratus (Dalman) and Trechnites psyllae (Ruschka), and 14 predators, Anthocoris nemoralis (F.), Anthocoris nemorum (L.), Orius horvathi (Reuter), Orius vicinus

(1) Current adress : Insect Biology \& Population Management Research Laboratory, P.O. Box 748, Tifton, Georgia, 31793-0748, U.S.A.
(Ribaut) (Het. : Anthocoridae); Heterotoma meriopterum (Scopoli), Campyloneura virgula (HerrichSchäffer), Orthotylus nassatus (F.) (Het. : Miridae) ; Stethorus punctillum (Weise), Scymnus rubromaculatus (Goeze), Scymnus subvillosus (Goeze), Coccinella septempunctata L. (Col. : Coccinellidae) ; Chrysoperla carnea (Stephens) (Neur. : Chrysopidae); Coniopteryx borealis Tjeder (Neur. : Coniopterygidae) and the mite, Allothrombium fuliginosum Hermann. All these species are polyphagous, but only the first three are tied to pear psylla. It was shown that the orchard environment, which included hawthorn and nettle, is a reservoir of the main pear psylla enemies.

This paper indicates activity periods of the main species, their succession during the year, and their relative abundance. 


\section{MATERIALS AND METHODS}

Orchards and sampling methods will be described in another publication (HERARD, 1986). The orchards are located in the Avignon and Toulouse regions, and pear varieties are "Yellow Williams" at Avignon, "Red Williams", "Beurré Hardy" and "Dr. Guyot" at Toulouse. Pear psylla adults and predators were sampled every 2 weeks by beating branches.

Pear psylla larvae and mummies were collected by cutting twigs bearing them and holding them until emergence of parasites. For each sample, numbers of parasites and predators and numbers of individuals in each species were counted. Diversity of dominant psylla enemy species and degree of this dominance in each sample was determined using the dominance diversity index expressed by Shannon's formula (WILHM, 1972) presented below.

\section{RESULTS}

\section{A. Evolution of pear psylla populations}

In the abandoned orchard at Avignon, the pear psylla population was high in May 1981, in spite of the precocious action of parasites, $P$. mitratus and T. psyllae (fig. 1). Due to the almost simultaneous proliferation of 13 main predators (fig. 1) between late May and late July, the psylla population decreased to a very low level. Predators then became rare, but lack of tender twigs in summer prevented reappearance of the psylla. Appearance of tender twigs in autumn and absence of predators again allowed the pear psylla population to increase.

In the commercial orchard at Toulouse, the pear psylla population increased slower than at Avignon during the spring, but finally reached a higher level apparently because of the following factors :

(1) predators were less numerous;

(2) only 4 main species, Orius spp., A. nemoralis, $C$. virgula and $H$. meriopterum proliferated in June and July, but only 3 of them were abundant at the same time (fig. 2) ;

(3) secondary predators preceded or succeeded the main ones at Toulouse, whereas they occurred simultaneously at Avignon. In fact, Coccinellidae, Chrysopidae and mites occurred in June and July at Avignon (fig. 1) whereas at Toulouse, Syrphidae occurred in May, and Coccinellidae, Nabidae and Chrysopidae mainly occurred at the end of the summer and in autumn (fig. 2) ;

(4) heavier density of tender twigs on trees at Toulouse created a larger dispersion of prey ;

(5) unlike the situation at Avignon, presence of tender twigs on some trees during summer and autumn contributed to maintain a semi-endemic pear psylla population at Toulouse ;

(6) absence of effective predators in late summer at Toulouse contributed to an increase in pear psylla population at the end of September. However, this increase was limited by the effect of the late-occurring parasite, T. psyllae, and by a third population peak of Orius spp.

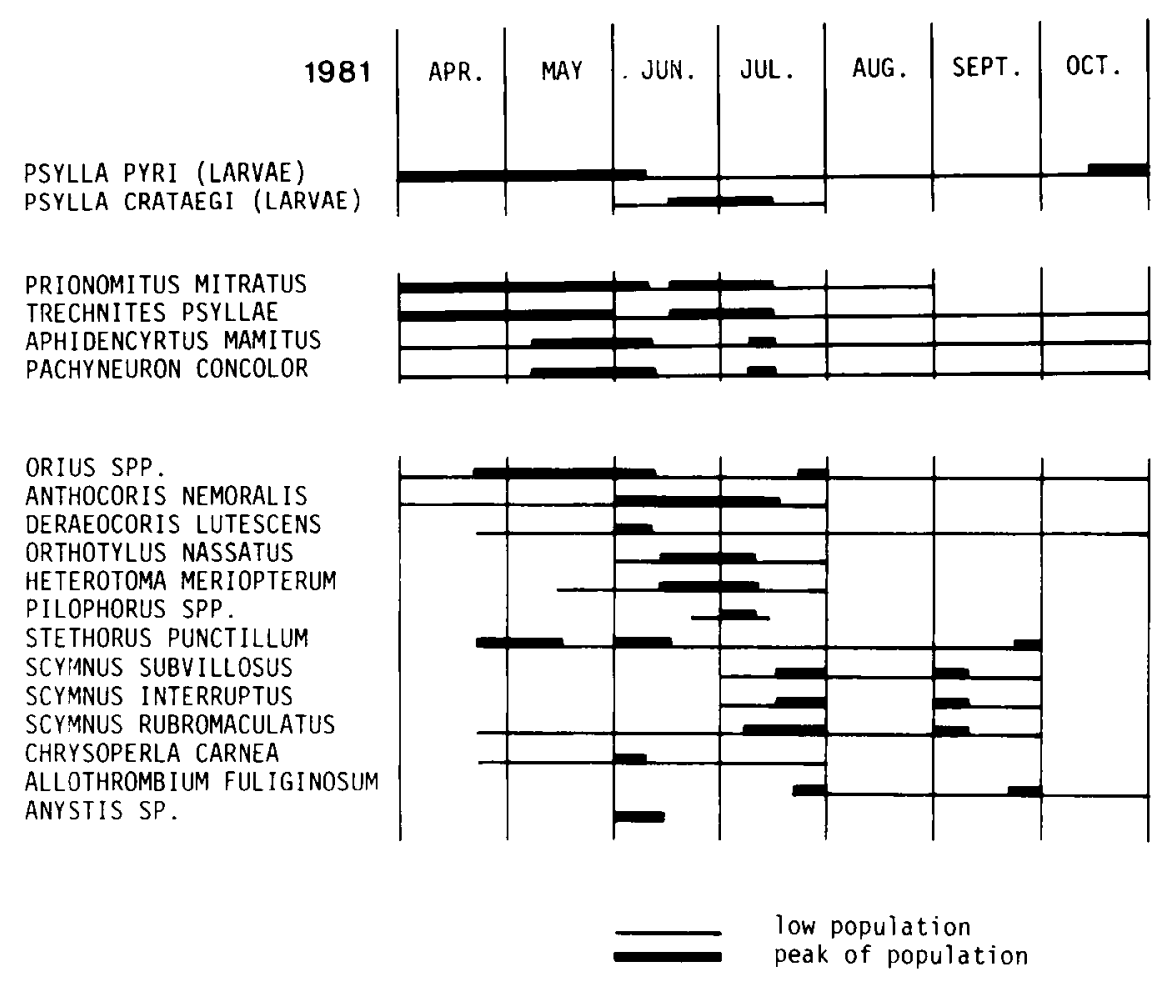




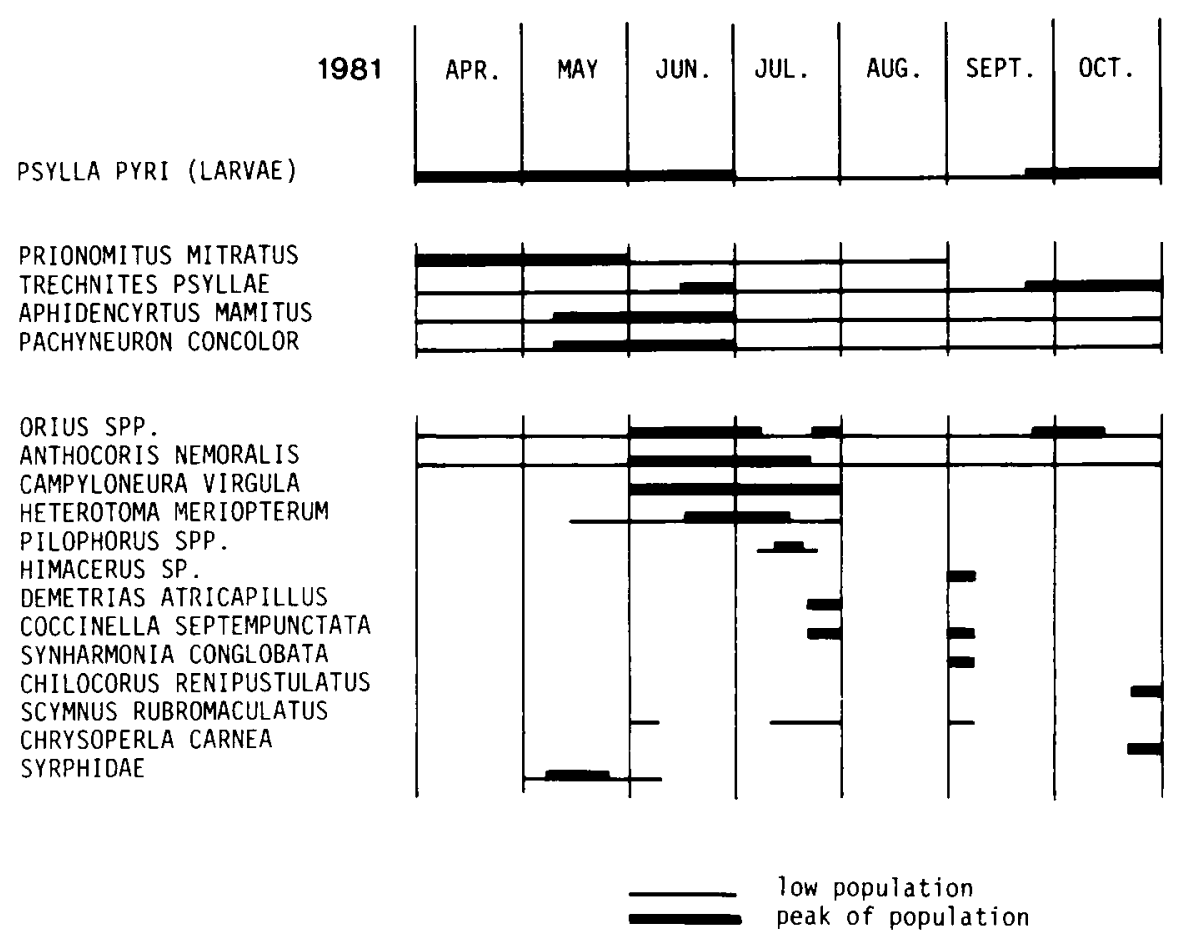

Figure 2

Activity periods of pear psylla enemies at Toulouse (1981).
Périodes d'activité des ennemis du psylle du poirier à Toulouse (1981).

\section{B. Activity periods of pear psylla enemies}

\section{Parasitoids}

The 2 encyrtids, $P$. mitratus and $T$. psyllae, contributed to control the psylla on pear trees in our collection sites. According to NGUYEN (Pers. Comm.), $P$. mitratus is usually abundant and is one of the main limiting factors of the pear psylla in Toulouse during April-May of each year. T. psyllae was more abundant on pear psylla larvae in April-May in Avignon than in Toulouse. This parasite remained active late in autumn, occurring on pear psylla mummies collected in late October in Toulouse.

\section{Hyperparasitoids}

The 2 psylla hyperparasites, Aphidencyrtus mamitus (Walker) (Encyrtidae) and Pachyneuron concolor (Foerster) (Pteromalidae) were reared from many $P$. pyri mummies collected in orchards, but were more abundant at Avignon than at Toulouse.

\section{Predators}

Predators were the most efficient and most abundant limiting agents on pear psylla populations. Their impact seems to be related to three main factors: voltinism, although some univoltine predators can be very voracious, abundance of individuals, and duration of their activity period in the orchard. Two main insect orders were present and included many species, i.e. 25 species of Heteroptera and 14 species of Coleoptera, all Coccinellidae.

\section{a) Heteroptera}

Anthocoridae, mainly Orius spp. and $A$. nemoralis, were the major predators, based on their abundance in the orchards from early spring to late autumn. These are polyvoltine species. Orius spp. have 3 generations per year, and Anthocoris spp. have 2 and sometimes 3 generations in Southern France. At Avignon, the population peak of $A$. nemoralis occurred from mid-June to early July. At Toulouse, it occurred in the first half of July. Orius spp. produced 2 population peaks at Avignon during the second half of May and in late July. There were 3 peaks at Toulouse, the first during the second half of June, the second in late July, and the third in late September to early October, during the last $P$. pyri generation. Usually, Orius populations corresponded to the presence of phytophagous mite populations. However, development of the third population peak at Toulouse corresponded to pear psylla abundance.

The collected Miridae were univoltine species, and their abundance was generally lower than that of the Anthocoridae. However, 3 species were rather abundant :

(i) C. virgula occured mainly at Toulouse from early June to late July, with a higher peak during the first 3 weeks of June ;

(ii) $O$. nassatus occured mainly at Avignon from early June to late July, with a high peak during the last 2 weeks of June and the first week of July;

(iii) $H$. meriopterum occured from mid-May to late July with a peak in late June at Avignon and in mid-July at Toulouse. 
The Mirid, Deraeocoris lutescens (Schilling), was encountered regularly in small numbers from late April to late October at Avignon. At Toulouse, it was found in very small numbers in early June, in September and in early October.

Other Mirids were encountered sporadically, except Pilophorus spp., which were collected mainly in early July at Avignon and in mid-July at Toulouse.

\section{b) Coleoptera}

Only 3 species of Coccinellidae, belonging to the tribe Scymnini, were abundant, including $S$. punctillum and S. subvillosus at Avignon and S. rubromaculatus at Toulouse and Avignon. Although polyphagous, these species are generally more associated with populations of mites and aphids, as shown in a literature review presented by HERARD (1986). We observed 3 population peaks of $S$. punctillum : midMay, mid-June, and late September at Avignon, on pear trees infested mainly by $P$. pyri and a little by mites. Three peaks of $S$. subvillosus occurred : late June, late July and early September. We observed $S$. rubromaculatus at Avignon from July to September, noting a population peak in mid-July. At Toulouse, we encountered it in small numbers in early June and late July.

Large Coccinellidae were encountered sporadically and in small numbers. Most collected Coccinellidae produced 2 to 4 generations a year, except Adalia bipunctata L., which apparently had only one. According to IPERTI (1974), a number of climatic and ecological factors establish the activity period of each coccinellid independent of biological characteristics of the species. High temperatures in July and August reduce the fecundity of the polyvoltine species and involve a summer break of the univoltine ones. All predaceous coccinellids are polyphagous, but they have preferences, and the nature of the food influences their voracity and fecundity (IPERTI, 1974).

\section{c) Other predators}

Two other groups of pear psylla predators were observed. Neuroptera: Chrysopidae, was represented by the species $C$. carnea. The mite, $A$. fuliginosum which was mainly observed at Avignon from late July to late October, produced a population peak in late September.

\section{Dominance diversity in pear psylla enemies}

\section{The dominance diversity index}

We determined diversity of dominant species and degree of this dominance in each sample. Numerous expressions of diversity and dominance have been proposed by many authors. WILHM (1972), for example, made an inventory and a critique. We have chosen to use the dominance diversity index expressed by SHANNON's formula (WILHM, 1972), presented briefly here. According to WILHM, diversity has at least 2 meanings: "In one sense, diversity refers to species richness in terms of numbers of species in an area. The more species that are present, the greater the diversity. A second approach to diversity is based on relative composition of species in an area. This measures how equally individuals are distributed among the species. The more equal the distribution, the greater the diversity."

WHITTAKER (1965) referred to this interpretation as dominance diversity. Dominance diversity may be expressed by different mathematical equations, such as SHANNON's formula :

$$
d=-\sum\left[\left(n_{i} / n\right) \log _{2}\left(n_{i} / n\right)\right],
$$

where $n_{i}$ is the number of individuals of the species (i) and $n$ the total number of individuals in the sample. After the change of base :

$$
\begin{aligned}
& \log _{2}\left(n_{i} / n\right)=\frac{\log \left(n_{i} / n\right)}{\log 2}, \\
& d=-\sum\left[\left(n_{i} / n\right) \frac{\log \left(n_{i} / n\right)}{\log 2}\right]
\end{aligned}
$$

According to WILHM, SHANNON's formula is the most satisfactory because of several features :

"First, it expresses the relative importance of each species collected, not merely the relationship between total numbers of species and of individuals. The diversity index ' $d$ ' is not affected by sample size. The index ' $d$ ' is dimensionless, and numbers, biomass, or calories in any units can be used as basic data in the equation."

"The value of ' $\mathrm{d}$ ' can vary from zero to any positive number. A value of zero is obtained when all individuals belong to the same species. The maximum value of ' $d$ ' depends on the number of individuals counted and is obtained when no 2 individuals belong to the same species."

When " $d$ " is weak, only a few species are very dominant. When "d" is average, several species dominate moderately. When " $d$ " is strong, many species are about equally dominant. Since the total number of individuals in the samples has been variable, the possible maximum values of " $\mathrm{d}$ " are very different. The maximum value of " $d$ " is calculated in considering that, in a given sample, all the individuals collected could belong to all different species; the number of species would be equal to the number of individuals collected, with $n_{i}=1$. To-ease the comparison of real values of " $d$ ", we have expressed them in percent of their theoretical maximum values. These values are represented by histograms in figure 3 . Since dominance diversity can be equal for 2 different groups of species, each histogram is topped by initials of the dominant species in the sample.

\section{Pear psylla enemies at Avignon}

Concerning dominance diversity of $P$. pyri enemies at Avignon, we observed at first an average value in late April (fig.3a), when the most precocious predators became active. Among them, Orius spp. and $S$. punctillum shared an average dominance. The parasite $T$. psyllae appeared in early May, followed in midMay by the hyperparasite $A$. mamitus. Orius spp. and $S$. punctillum pullulated at this time too. These 4 enemies dominated rather clearly in mid-May, fact which explains the rater weak value of index " $d$ ". 


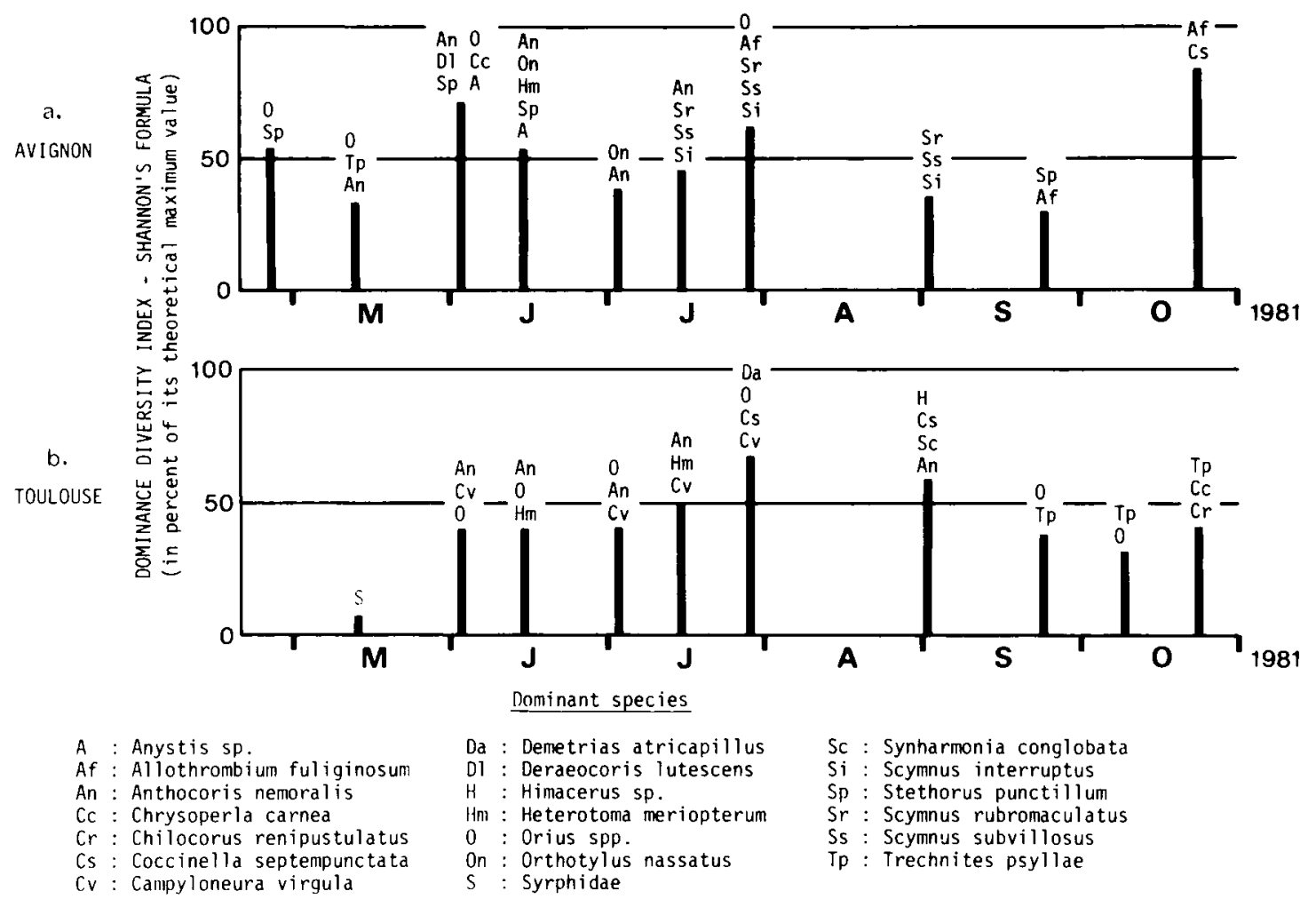

Figure 3

Dominance diversity in pear psylla enemies at Avignon and Toulouse, in 1981

During June and July index " $d$ " deviated very little from the average value, which means the dominance was shared rather equally among the several species. In this case, the number of dominant species varied from 4 to 6 . However, the composition of the dominant species group changed from early June to late July. Only $A$. nemoralis was regularly abundant during these 2 months. Moreover, in early June we also found great numbers of Orius spp., C. carnea, $D$. lutescens, $S$. punctillum and mite Anystis sp. In mid-June, $O$. nassatus and $H$. meriopterum joined the dominant group. Index " $d$ " decreased in early July because only 2 species dominated more heavily : $O$. nassatus and $A$. nemoralis. Then index " $\mathrm{d}$ " took again an average value in mid-July and in late July, but the group of dominant species was then essentially composed of Scymnini coccinellids, S. rubromaculatus, S. subvillosus and S. interruptus. Orius spp. became abundant again in late July. In early September, Scymnini species dominated even more, which explains the decrease of index "d". Index " $d$ " continued to decrease in late September, because only 2 species dominated clearly, A. fuliginosum and $S$. punctillum. In late October index " $\mathrm{d}$ " increased heavily because a rather high number of species, remained in the orchard, each represented by a very small number of individuals. However, we noted a very slight dominance of $C$. septempunctata and of $A$. fuliginosum.

In conclusion, we did not find at Avignon any example of a very dominant species at any particular moment. On the contrary, we generally observed a
Diversité des ennemis dominants du psylle du poirier à Avignon et Toulouse, en 1981.

rather great diversity in dominance, equally shared by the various groups of insects.

The slight general raising of the index in July at Avignon and Toulouse corresponded with arrival of many univoltine species, and its reduction in AugustSeptember, to emigration of species. More accidental fluctuations, namely at Avignon, were due probably to the influence of environment.

\section{Pear psylla enemies at Toulouse}

At Toulouse, we calculated (fig. 3b) in mid-May a very weak index " $d$ ", resulting from dominance of one group of species, the syrphids, associated with an aphid outbreak on pear trees. These syrphids contributed to their elimination. From early June to midJuly, index " $d$ " remained at an average value, which expresses a moderate dominance of several species. In fact, only 4 species were dominant during June and July at Toulouse: $A$. nemoralis, $C$. virgula, Orius spp. and $H$. meriopterum.

Unlike the situation observed at Avignon, the Toulouse biocomplex did not evolve very much in composition during the 2 months of maximum predator activity. Furthermore, we noted at Toulouse the absence of 2 enemies which were abundant at Avignon, $O$. nassatus and the Scymnini group. In late July the dominant species group diversified (thus increasing index "d") due to appearance of Demetrias atricapillus (L.) and of C. septempunctata as in early September, with the appearance of Himacerus sp. and of Synharmonia conglobata (L.). In late September and in early October, index " $d$ " decreased again, 
indicating a smaller number of species sharing heavier dominance. During this period, a new outbreak of Orius spp. and of $T$. psyllae occurred. Finally, we noted in late October a relative abundance of $C$. carnea and Chilocorus renipustulatus (Scriba).

The number of dominant species at each sampling date was generally higher at Avignon than at Toulouse, especially, in June-July 1981. Fifteen main beneficial arthropods occurred at Avignon and only 8 at Toulouse, which may explain why control of $P$. pyri was much better in Avignon.

\section{CONCLUSION}

In the orchards observed in Southern France in 1981, efficiency of the pear psylla parasites and predators was based on the following :

(1) some beneficials, $P$. mitratus, $T$. psyllae, Orius spp. and $A$. nemoralis, were present in orchards during almost the whole activity period of the pear psylla, i.e. 5 to 7 months ;

(2) other beneficial arthropods occurred for shorter periods ( 2 weeks to 4 months), but their peaks of activity did not coincide, so that predation pressure on the pear psylla remained fairly high for a long time ;

(3) some species, i.e. P. mitratus and T. psyllae, occurred very early in the season, and some species, T. psyllae and Orius spp., occurred very late ;

(4) most of beneficial arthropods had a very high peak of activity in June and July.

At Avignon as at Toulouse, control of the pear psylla was carried out basically by a few polyphagous beneficial arthropods, showing a degree of preference for the pest : A. nemoralis, Orius spp., P. mitratus, $T$. psyllae. However, the impact of these major enemies, represented in orchards by many individuals, was generally too low to assure total control of the pest. Their effect was supplemented by action of many other less specific species which occurred at different periods of the year. Depending on the species, minor enemies were either very numerous for a short time (O. nassatus, $H$. meriopterum), or few but present for the whole summer (D. lutescens, some Coccinellidae). Presence of many minor enemies, apparently made the difference observed at Toulouse and at Avignon, in control of the pest. At Avignon, where the minor beneficial arthropods were the most numerous in June-July, control was best.

Observations made at Toulouse and Avignon showed that a small number of rather specific beneficial arthropods was essential to reduce the populations notably, but not sufficient to control the pear psylla. Their action was enhanced by minor enemies; the higher the number of minor enemy species occuring simultaneously in June-July, the greater the control of the pear psylla.

Recu le 25 janvier 1985 Accepté le 30 avril 1985.

\section{ACKNOWLEDGMENTS}

We very warmly thank J. P. Manguin and J. R. ORTIZ who authorized insect collections in their orchards at Avignon and at Toulouse, and R. RiEUX (I.N.R.A., Montfavet), G. FAUVEL (I.N.R.A., Montpellier), P. ATGer (I.N.R.A., St. Marcel-lesValence) and B. D. PERkins (EPL, USDA, Behoust) who reviewed the manuscript.

\section{REFERENCES}

Bouyjou B., Canard M., Nguyen T. X., 1984. Analyse par frappage des principaux prédateurs et proies potentielles en verger de poiriers non traité, p. 148-166. In : Colloque international sur la lutte intégrés contre les psylles du poirier, Toulouse, 27-29 sept. 1983, Bull. OILB/SROP, VII (5), 388 p.

Herard F., 1986. Annotated list of the entomophagous complex associated with pear psylla, Psylla pyri (L.) (Hom. : Psyllidae) in France. Agronomie, 6 (1)

Iperti G., 1974. Les coccinelles, p. 111-121. In : Les organismes auxiliaires en verger de pommiers, OILB/SROP, Broch. 3, $242 \mathrm{p}$.
Nguyen T. X., Delvare G., 1984. Bioconose des psylles du poirier (Psylla pyri L. et Psylla pyrisuga Foerster) dans la région toulousaine, France, p. 191-197. In : Colloque international sur la lutte intégrée contre les psylles du poirier, Toulouse, 27-29 sep. 1983, Bull. OILB/SROP, VII (5), 388 p.

Whittaker R. H., 1965. Dominance and diversity in land plant communities. Science, 147, 250-260.

Wilhm J., 1972. Ciraphic and mathematical analyses of biotic communities in polluted streams. Annu. Rev. Entomol., 17, 223-252. 